\title{
PERSEPSI MASYARAKAT KOTA BENGKULU TERHADAP PAHAM ISLAM MODERAT
}

\author{
Wahyu Abdul Jafar \\ LAIN Bengkulu,wahyuabduljafar@gmail.com
}

Diterima: 13 Maret 2018

Direvisi : 2 Mei 2018

Diterbitkan: 30 Juni 2018

\begin{abstract}
This research was conducted to describe the perception of resident of bengkulu about moderate Islamic understanding, then from the findings of field data will be conducted in depth analysis how exactly the perception of resident of bengkulu about moderate Islamic understanding. In collecting the research data, researchers used purposive sampling technique to facilitate collecting data from informants. While the data collection techniques used are interviews and documentation. From research in the field of researchers managed to get important conclusions namely, resident of bengkulu has some perception about moderate Islamic understanding, among others: first, Moderate Islamic understanding is the teachings of Islam that is tasamuh (tolerant), tawazun (balanced), i'tidal (straight) and tawasuth (mediocre). Secondly, Moderate Islamism is the Islamic teaching that is Rahmatan Lil Alamin. Thirdly, moderate Islamic understanding is a bumanist teaching, bumanistic, gentle, polite, not anarchic and peace-loving. Fourthly, Moderate Islamism is an Islamic teacbing that opens itself with progress and in barmony with the concept of Indonesian statehood. Fifth, Moderate Islamism is the Islamic teachings of Islam that prioritize the value of the unity and integrity of the nation and the state. Sixth, Moderate Islamism is the teachings of Islam which emphasizes the amar ma'rufnya side of the nabi mungkarnya side. Seventh, Moderate Islamism is a strictly Islamic teaching for the afterlife and flexible for world affairs. Eighth, Moderate Islamism is a liberal and perverted teaching of Islam. Ninth, Moderate Islamism is an Islamic teaching that is heretical and weakens the Islamic ummah. Tenth, Islamic understanding Moderate is the Islamic teaching that is a mirage and divide the Muslims.
\end{abstract}

Keywords: Islam, Moderate, Perception, Urgencyness

\begin{abstract}
Abstrak
Penelitian ini dilakukan untuk mendeskripsikan persepsi Masyarakat Kota Bengkulu terhadap Paham Islam Moderat, kemudian dari temuan data dilapangan akan dilakukan analisis secara mendalam bagaimana sebenarnya persepsi Masyarakat Kota Bengkulu terhadap Paham Islam Moderat. Dalam mengumpulkan data penelitian, peneliti mengunakan Teknik purposif sampling untuk memudabkan mengumpulkan data dari informan. Sedangkan teknik pengumpulan data yang digunkan adalah wawancara dan dokumentasi. Dari penelitian dilapangan peneliti berbasil mendapatkan kesimpulan penting yakni, Masyarakat Kota Bengkulu memiliki beberapa persepsi tentang paham Islam moderat, antara lain: pertama, Paham Islam Moderat adalah ajaran Islam yang bersifat tasamuh (toleran), tawazun (berimbang), i'tidal (lurus) dan tawasuth (sedanga-sedang). Kedua, Paham Islam Moderat adalah ajaran Islam yang bersifat Rahmatan Lil Alamin. Ketiga, Paham Islam Moderat adalab ajaran Islam yang bersifat bumanis, lembut, santun, tidak anarkis dan cinta damai. Keempat, Paham Islam Moderat adalab ajaran Islam yang membuka diri dengan kemajuan dan selaras dengan konsep kenegaraan Indonesia. Kelima, Paham Islam Moderat adalah ajaran Islam Islam yang mengedepankan nilai nilai persatuan dan keutuban berbangsa dan bernegara. Keenam, Paham Islam Moderat adalah ajaran Islam yang lebih menekankan sisi amar ma'rufnya dari pada sisi nabi mungkarnya. Ketujuh, Paham Islam Moderat adalah ajaran Islam yang bersifat tegas untuk urusan akbirat dan lentur untuk urusan dunia. Kedelapan, Paham Islam Moderat adalah ajaran Islam yang bersifat liberal dan sesat. Kesembilan, Paham Islam Moderat adalah ajaran Islam yang bersifat bid'ah dan melemabkan umat Islam. Kesepuluh, Paham Islam Moderet adalah Ajaran Islam yang bersifat fatamorgana dan memecab belah umat Islam.
\end{abstract}

Kata kunci: Islam, Moderat, Persepsi, Urgensi

\section{PENDAHULUAN}

Paham Islam Moderat merupakan suatu paham yang mengedepankan rasa saling hormat-menghormati, tidak saling salahmenyalahkan, tidak saling merasa paling benar sendiri, dan bersedia berdialog ketika 
terjadi sebuah perbedaan. Paham Islam Moderat ini sangat urgen untuk disebarkan di masyarakat luas guna menangkal berkembangnya paham radikal ${ }^{1}$ dalam agama Islam. Paham radikal apabila dibiarkan tumbuh subur ditengah masyarakat tentu akan menimbulkan sikap intoleransi ketika menyikapi perbedaan pandangan dalam agama yang bisa mengancam keutuhan Negara Kesatuan Republik Indonesia (NKRI).

Masih belum hilang dalam ingatan kita, fenomena kasus intoleransi dalam beragama yang terjadi sepanjang dua tahun terakhir, yakni kasus pembakaran tembat ibadah umat muslim dan 70 rumah umat muslim di tolikara papua yang terjadi pada hari jum'at tanggal 17 juli $2015^{2}$ serta kasus pembakaran satu vihara dan empat kelenteng di tanjung balai sumatera utara pada tanggal 29 juli 2016. ${ }^{3}$

Contoh kasus di atas tidak menutup kemungkinan bisa menular juga ke Kota Bengkulu apabila tidak dilakukan upaya pencegahan melalui penguatan Paham Islam Moderat. Apalagi masyarakat Kota Bengkulu terdiri dari masyarakat yang heterogen. hal ini dapat dilihat pada tabel dibawah ini,

\begin{tabular}{|l|l|l|l|l|l|}
\hline \multirow{2}{*}{ Kategori } & \multicolumn{5}{|c|}{ Jenis Agama } \\
\cline { 2 - 6 } & Islam & Protestan & Katolik & Hindu & Budha \\
\hline $\begin{array}{l}\text { Pemeluk } \\
\text { Agama }\end{array}$ & 368.229 & 58.706 & 129 & 540 & 1.059 \\
\hline Kategori & Masjid & $\begin{array}{l}\text { Gereja } \\
\text { Protestan }\end{array}$ & $\begin{array}{l}\text { Gereja } \\
\text { Katolik }\end{array}$ & Pura & Vihara \\
\hline $\begin{array}{l}\text { Rumah } \\
\text { Ibadah }\end{array}$ & 389 & 2 & 12 & 2 & 2 \\
\hline
\end{tabular}

1 Radikalisme merupakan fenomena modern dan kontemporer, dan merupakan reaksi terhadap munculnya nasionalisme sekular. Ideologi radikalisme menggambarkan respon langsung terhadap munculnya negara-bangsa yang merdeka. Militansi dan atavisme radikalisme Islam menggambarkan sistesis kreatif revivalisme dan reformisme. Gerakan radikal berpandangan kolot dan sering menggunakan kekerasan dalam mengajarkan keyakinan mereka. Syamsul Bakri, "Islam dan Wacana Radikalisme Kontemporer". DINIKA. Vol. 3 No. 1, Januari 2004, h. 3. Januari 2017

2 www.tempo.co, didownloud pada tanggal 30

3 www.m.tribunews.com, didownloud pada tanggal 30 Januari 2017

\section{Sumber: Data Badan Pusat Statistik Kota Bengkulu $^{4}$}

Keberagaman beragama yang ada di Kota Bengkulu perlu dikelola dengan arif dan bijaksana untuk menghindari terjadinya kasus intoleransi beragama. Upaya pencegahan terjadinya kasus intoleransi beragama seperti yang dicontohkan di atas bisa dengan dilakukan sejak dini yakni dengan cara mengetahui persepsi masyarakat kota Bengkulu terhadap Urgensi Paham Islam moderat. Mengetahui persepsi masyarakat ini sangat penting sekali untuk menjadi barometer awal dalam mencegah terjadinya kasus intoleransi. Ada beberapa contoh sikap yang bisa memicu terjadinya sikap intolerani dan konflik ditengah-tengah masyarakat Kota Bengkulu apabila dibiarkan begitu saja tanpa ada penanganaan yang khusus, hal ini sebagaimana kutipan wawancara pra-survey, antara lain:

"Katanya umat Islam ikut Nabi Muhammad tapi buktinya banyak amalan ibadah mereka yang buat-buat sendiri. Yasinan, tablilan dan selametan itu dari budaya bindu tapi malah mereka lakukan, abli bid'ah semua mereka kalau masuk neraka baru tau rasa nanti" ${ }^{5}$

Wawancara selanjutnya, "lebih baik sholat jama'ah disini saja mas jangan ditempat lain, tidak sah nanti karena imam nya melafadkan niat sebelum takbir. Melafalkan niat kalau menurut ustat kami termasuk bid'ah karena tidak ada hadisnya. Logikanya kalau melafalkan niat ajaran dari Nabi tentu ada hadisnya kan."

Wawancara selanjutnya, "Jangan campurkan agama dan budaya. Agama ya agama budaya ya budaya. Masyarakat kita ini banyak yang

4 BPS Provinsi Bengkulu, Provinsi Bengkulu Dalam Angka 2016, (Bengkulu : Perum Percetakan Negara RI Cabang Bengkulu, 2016), h. 182-184

5 Wawancara dengan Bapak Ahmad pada tanggal 29 Maret 2017.

24 Maret 2017. 
salah kaprah mengikuti budaya malah meningalkan ajaran agama Islam yang murni”.7

Wawancara selanjutnya, "saya males sholat di masjid sana mas, nga sealiran dengan saya. Sububnya pakai qunut".

Wawancara selanjutnya, "Di masjid sini pernah tengkar mas antar jama'ah gara-gara habis sholat harus wiridan setelah sholat berjama'ah atan wiridan sendiri-sendiri" 9

Dari data pra-survey di atas dapat diketahui bahwa bibit-bibit munculnya sikap intoleransi sudah ada dan apabila dibiarkan begitu saja akan berdampak pada berkembangnya paham intoleran dalam beragama yang tidak menutup kemungkinan munculkan sikap radikal.

Upaya deteksi dini ini apabila dimaksimalkan bisa menjadi benteng yang kokoh dalam membentengi masyarakat kota Bengkulu dari paham-paham yang radikal. Berdasarkan fakta inilah peneliti merasa tertarik dan ingin melakukan kajian secara mendalam tentang Persepsi Masyarakat Kota Bengkulu Terhadap Paham Islam Moderat.

Berdasarkan latar belakang masalah yang telah peneliti paparkan di atas, maka peneliti membuat rumusan masalah, Bagaimana Persepsi Masyarakat Kota Bengkulu Terhadap Paham Islam Moderat?

Artikel ini adalah hasil penelitian dalam rangka mengetahui secara detail Persepsi Masyarakat Kota Bengkulu Terhadap Paham Islam Moderat.

Penelitian terkait Persepsi Masyarakat Kota Bengkulu Terhadap Urgensi Paham Islam Moderat belum pernah dilakukan sebelumnya, namun ada beberapa penelitian yang memiliki keterkaitan dengan penelitian ini, antara lain:

27 Maret 2017

7 Wawancara dengan Bapak Rijal pada tangal

8 Wawancara dengan Bapak Muzakki pada tangal 24 Maret 2017

${ }^{9}$ Wawancara dengan Bapak Yanto pada tangal 29 Maret 2017.
Pertama, Miftahuddin ${ }^{10}$, melakukan penelitian yang berjudul "Islam Moderat Konteks Indonesia Dalam Perspektif Historis". Penelitian yang dilakukan oleh Miftahuddin ini mencoba melihat kembali bagaimana cara memahami Islam dan berIslam yang seharusnya diterapkan dalam konteks Indonesia sehingga tidak terjebak ke dalam ekstrimitas yang berlebihan. Dari penelitianya dihasilkan kesimpulan bahwa Paham "Islam moderat", pada dasarnya hanyalah sebatas tawaran yang semata-mata ingin membantu masyarakat pada umumnya dalam memahami Islam. Bersikap moderat dalam ber-Islam bukanlah suatu hal yang menyimpang dalam ajaran Islam, karena hal ini dapat ditemukan rujukannya, baik dalam Alquran, al-Hadits, maupun perilaku manusia dalam sejarah. Mengembangkan pemahaman "Islam moderat" untuk konteks Indonesia dapatlah dianggap begitu penting. Bukankah diketahui bahwa di wilayah ini terdapat banyak paham dalam Islam, beragam agama, dan multi-etnis. Paham "Islam moderat mengajak, bagaimana Islam dipahami secara kontekstual, memahami bahwa perbedaan dan keragaman adalah sunnatullah, tidak dapat ditolak keberadaannya. Jika hal ini diamalkan, dapat diyakini Islam akan menjadi agama rahmatan lil alamin. Penelitian yang dilakukan oleh Miftahuddin berbeda dengan yang peneliti kaji dalam beberapa hal, antara lain: pertama jenis penelitian. Penelitian yang dilakukan oleh Miftahuddin jenisnya library research sedangkan jenis penelitian yang dilakukan oleh peneliti jenisnya field research. Perbedaan yang kedua dari fokus penelitiannya, penelitian yang dilakukan oleh Miftahuddin fokus penelitianya adalah Historis Islam Moderat yang ada di Indonesia sedangkan penelitian yang penulis lakukan fokusnya adalah persepsi masyarakat

10 Miftahuddin, Dosen Prodi Ilmu Sejarah, Jurusan Pendidikan Sejarah, FISE UNY, "Islam Moderat Konteks Indonesia Dalam Perspektif Historis". 
kota Bengkulu terhadap urgensi Paham Islam Moderat.

Kedua, Imam Mustofa, melakukan penelitian yang berjudul "persepsi dan resistensi aktifis muslim kampus terhadap paham dan gerakan Islam radikal (studi di perguruan tinggi di propinsi lampung)". Penelitian ini berusaha menelisik dan mengungkap ketahanan mahasiswa di propinsi Lampung terhadap paham dan gerakan Islam radikal. Penelitian ini adalah penelitian lapangan (field research) yang bersifat kualitatif. Populasi penelitian ini adalah mahasiswa di empat perguruan Tinggi di propinsi Lampung, yaitu mahasiswa Universitas Lampung (Unila) mahasiswa Institut Agama Islam Negeri (IAIN) Raden Intan Lampung, mahasiswa Universitas Muhammadiyah Metro, dan mahasiswa Sekolah Tinggi Agama Islam Ma'arif (STAIM) Metro. Teknik sampling yang digunakan adalah purposive sampling. Teknik pengumpulan data dengan cara wawancara dan dokumentasi. Data yang terkumpul dianalisis dengan metode deskriptif-analitis. Sementara pendekatan yang digunakan dalam penelitian ini adalah pendekatan fenomenologi dan interaksi simbolik. Hasil penelitian ini menunjukkan bahwa mayoritas aktifis memandang gerakan Islam radikal sebagai ancaman terhadap Negara Kesatuan Republik Indonesia (NKRI). Namun demikian, keberadaan $23 \%$ responden yang berpandangan sebaliknya, yaitu bahwa Islam radikal tidak membahayakan eksistensi NKRI, tidak dapat dikatakan sebagai angka yang tidak signifikan. Pandangan mayoritas atau minoritas tidak selalu dapat diasosiasikan dengan latar belakang organisasi para aktivis Muslim kampus. Mereka mempunyai ketahanan yang cukup kuat terhadap pengaruh paham dan gerakan Islam radikal. Mereka juga mempunyai resistensi yang cukup kuat terhadap berbagai media dan sarana yang biasa digunakan kalangan Islam radikal untuk melakukan propaganda dan mencari kader. Kuatnya ketahanan mahasiswa tersebut dipengaruhi oleh faktor pendidikan, pemahaman agama serta faktor lingkungan dan pergaulan. Secara hirarkis mayoritas responden akan melakukan resistensi melalui cara-cara yang santun dan persuasif; sekelompok responden tidak menunjukkan resistensi secara eksplisit; dan segelintir responden akan melakukan resistensi secara tegas. Ketegasan yang dimaksud tidak merujuk pada respon frontal, melainkan pada upaya untuk menopang sikap resistensi dengan beradu argumen. Penelitian yang dilakukan oleh Imam Mustofa ini berbeda dengan yang peneliti kaji. Perbedaan tersebuat terdapat dalam aspek, antara lain: pertama dari aspek fokus penelitian. Penelitian yang dilakukan oleh Imam Mustofa adalah resistensi aktifis muslim kampus terhadap paham dan gerakan Islam radikal sedangkan penelitian yang penulis lakukan fokusnya adalah persepsi masyarakat kota Bengkulu terhadap urgensi Paham Islam Moderat. Yang kedua dari aspek tempat penelitian, Penelitian yang dilakukan oleh Imam Mustofa bertempat di provinsi lampung sedangkan penelitan yang peneliti buat bertempat di kota Bengkulu.

\section{METODE PENELITIAN}

Dalam masalah metode penelitian, setidaknya ada beberapa poin yang perlu diperhatikan guna menunjang kesuksesan suatu penelitian yang dilakukan. Beberapa poin tersebut antara lain:

Pertama, Jenis penelitian yang peneliti lakukan guna mengungkapkan fakta terkait masalah Persepsi Masyarakat Kota Bengkulu Terhadap Urgensi Paham Islam Moderat adalah penelitian field research (penelitian lapangan). ${ }^{11}$ Dalam penilitian ini, peneliti akan

11 Case study research and field study research (Penelitian kasus dan penelitian lapangan) adalah penelitian yang bermaksud mempelajari secara intensif tentang latar belakang keadaan sekarang dan interaksi suatu sosial, individu, kelompok, lembaga dan masyarakat. Husaini Usman dan Purnomo Setiady 
melakukan pengalian data secara mendalam dan melakukan analisis secara intensif mengenai Persepsi Masyarakat Kota Bengkulu Terhadap Urgensi Paham Islam Moderat serta sebelumnya akan digali juga fakta-fakta tentang Persepsi Masyarakat Kota Bengkulu Terhadap Paham Islam Moderat itu sendiri, karena tidak menutup kemungkin masyarakat Kota Bengkulu berbeda persepsi dalam memahami Islam Moderat.

Kedua, Lokasi dan Waktu Penelitian. Sesuai dengan judul yang diangkat dalam penelitian ini, maka penelitian ini berlokasi di Kota Bengkulu. Alasan pemilihan lokasi ini karena Kota Bengkulu adalah pusat aktivitas dari penduduk bengkulu sehinga diharapkan data yang akan terkumpul berasal dari ragam varian yang lebih banyak. Sedangkan waktu pelaksanaan penelitian ini kurang lebih 6 (enam bulan) sebagaimana terlampir dalam jadwal penelitian.

Ketiga, Sumber Data Penelitian. Yang dimaksud sumber data dalam penelitian ini adalah subyek darimana data diperoleh. Dalam penelitian ini, ada beberapa sumber data yang digunakan oleh peneliti sebagai bahan rujukan, antara lain: Sumber Data Primer, sumber data primer peneliti dalam penelitian ini hanya katakata dan tindakan Masyarakat Kota Bengkulu Terhadap Urgensi Paham Islam Moderat. Sumber data primer tersebut oleh peneliti akan dicatat melalui catatan tertulis. Sumber Data Sekunder, Sumber data sekunder yaitu sumber yang secara tidak langsung berkaitan dengan objek penelitian ini tetapi dirasa sangat mendukung dalam penelitian, baik berupa buku-buku, artikel, koran, dan lain sebagainya yang berkaitan dengan Persepsi Masyarakat Kota Bengkulu Terhadap Urgensi Paham Islam Moderat.

Keempat, Teknik Pengumpulan Data. Dalam penelitian ini, peneliti menggunakan

Akbar, Metodologi Penelitian Sosial, Jakarta: PT Bumi Aksara, 2003), h. 5. dua teknik dalam mengumpulkan data-data penelitian, yaitu: Wawancara (Interview) dan dokumentasi. Peneliti melakukan wawancara mengunakan teknik wawancara tak tersetuktur. ${ }^{12}$ Teknik ini peneliti pilih karena lebih bersifat luwes dan dirancang agar sesuai dengan subjek dan suasana pada wawancara berlangsung. Teknik dokumentasi peneliti lakukan dengan cara mengumpulkan dokumen-dokumen dan literatur yang memiliki keterkaitan dengan persoalan Persepsi Masyarakat Kota Bengkulu Terhadap Urgensi Paham Islam Moderat.

Kelima, Teknik Analisis Data. Tehnik analisa data yang digunakan dalam penelitian ini adalah analisa kualitatif $^{13}$ dengan pola berfikir induktif. Analisa induktif yang dimaksud adalah analisa yang berangkat dari data yang bersifat khusus kemudian ditarik kesimpulannya yang bersifat umum. Dalam Penelitian kualitatif ini, peneliti akan melalui tiga komponen pokok, yaitu, data reduction, data display dan data conclusion drawing. ${ }^{14}$ Tiga komponen ini akan saling berkaitan baik sebelum, pada waktu dan setelah pelaksanaan pengumpulan data. Analisis ini pada umumnya disebut dengan model analisis mengalir atau flow model of analysis.

\section{TEORI PERSEPSI}

Persepsi merupakan suatu proses yang didahului oleh penginderaan yaitu merupakan

12 Teknik wawancara terbagi menjadi dua macam, wawancara berstruktur dan wawancara tak tersetuktur. Dalam wawancara berstruktur pertanyaan dan alternatif jawaban yang diberikan kepada interviewee telah ditetapkan terlebih dahulu, sedangkan pada pada wawancara tak terstruktur pertanyaanpertanyaan dapat diajukan secara bebas kepada subjek. Ibid., h. 180.

13 Analisa kualitatif artinya menguraikan data secara bermutu dalam bentuk kalimat yang teratur, runtun, logis, tidak tumpang tindih, dan efektif sehingga memudahkan pemahaman dan interpretasi data, Abdul Kadir Muahammad, Hukum dan Penelitian Hukum, (PT. Citra Aditya Bhakti, Jakarta, 2004)., h. 172)

14 Sugiyono, Model Penelitian kuantitatif kualitatif, (bandung: Alfabeta, 2010), h. 247-253 
proses yang berwujud diterimanya stimulus oleh individu melalui alat reseptornya. Untuk lebih memahami persepsi berikut adalah beberapa definisi peresepsi menurut pakar psikologi antara lain sebagai berikut:

Persepsi merupakan penafsiran yang terorganisir terhadap suatu stimulus serta mampu mempengaruhi sikap dan perilaku. Persepsi adalah proses penginterpretasian seseorang terhadap stimulus sensori. Proses sensori tersebut hanya melaporkan lingkungan stimulus. Persepsi menerjemahkan pesan sensori dalam bentuk yang dapat dipahami dan dirasakan.

Persepsi adalah penelitian bagaimana kita mengintegrasikan sensori ke dalan perspect obyek dan bagaimana kita selanjutnya menggunakan perspect itu untuk mengenali dunia (Perspect adalah hasil dari perspectual). ${ }^{15}$

Dengan demikian dari pengertianpengertian persepsi di satas dapat disimpulkan bahwa persepsi adalah proses pengorganisasian dan proses penafsiran/penginterpretasian seseorang terhadap stimulasi yang dipengaruhi oleh berbagai pengetahuan, keinginan dan pengalaman yang relevan terhadap stimulasi yang dipengaruhi perilaku manusia dalam menentukan tujuan hidupnya.

Agar individu dapat melakukan persepsi ada beberapa syarat yang harus dipenuhi, yaitu:

Adanya objek yang dipersepsikan, objek menimbulkan stimulus yang mengenai alat indera atau reseptor. Stimulasi dapat datang dari luar langsung mengenai alat indera (reseptor) dapat datang dari dalam yang langsung mengenai syaraf penerima (sensoris) yang bekerja sebagai reseptor.

Adanya alat indera atau reseptor yang cukup baik, yaitu alat untuk menerima stimulus. Di samping itu harus ada pula syaraf

15 Atkinson dkk, Pengantar Psikologi Jilid II, (Batam: Intereksa, 1987), h. 277 sensoris sebagai alat untuk meneruskan stimulus yang diterima reseptor ke pusat susunan syaraf sensoris yaitu otak sebagai pusat kesadaran. Dan sebagai alat untuk mengadakan respons diperlukan syaraf motoris.

Untuk menyadari atau untuk mengadakaan persepsi sesuatu diperlukan pula adanya perhatian yang merupakan langkah pertama sebagai suatu persiapan dalam mengadakan persepsi. Tanpa perhatian tidak akan terjadi persepsi. ${ }^{16}$

Persepsi seseorang terhadap suatu objek dapat berbeda dengan orang lain. Perbedaan tersebut dipengaruhi oleh berbagai faktor. Cara kita mempersepsikan situasi sekarang tidak bisa terlepas dari adanya pengalaman sensoris terdahulu. Kalau pengalaman terdahulu itu sering muncul, maka reaksi kita selalu menjadi kebiasaan secara ilmiah benar mengingat respon-respon perceptual yang ditunjukkannya.

Mungkin $90 \%$ dari pengalamanpengalaman sensoris kita sehari-hari dipersepsikan dengan kebiasaan yang didasarkan pada pengalaman terdahulu yang diulang-ulang. ${ }^{17}$ Oleh karena itu apa yang kita persepsikan pada suatu waktu tertentu akan tergantung bukan saja pada stimulusnya sendiri, tetapi juga pada latar belakang beradanya stimulus itu.

Seperti pengalaman-pengalaman sensoris kita yang terdahulu, perasaan kita pada waktu itu, prasangka-prasangka, keinginan-keinginan, sikap dan tujuan. Kalau di satu pihak proses kognitif saling berkaitan satu sama lain. Kita akan mulai dengan persepsi dianggap sebagai pertemuan antara kognisi dan kenyataan-kenyataan dan juga dianggap sebagai sumber utama dari aktivitas

16 Su'adah, Fauzik Lendriyono, Pengantar Psikologi, (Bayumedia Publishing,: Malang, 2003), h. 32

17 Dimyati Mahmud, Psikologi Suatu Pengantar, (Jakarta: BPFE, 1990), h. 41 
kognitif. ${ }^{18}$ Berikut ini dikemukakan beberapa faktor yang mempengaruhi persepsi seseorang menurut para ahli mengemukakan bahwa ada tiga faktor penting yang mempengaruhi persepsi yaitu pegetahuan (knowledge), harapan (expectations) dan penilaian (evaluation).

Ada tiga faktor yang mempengaruhi persepsi terhadap orang lain yaitu (a) keadaan stimulus dari orang yang dipersepsi, (b) situasi sosial tempat mana stimulus berada, (c) keadaan atau karakteristik dari orang yang mempersepsi (perseptor).

\section{KONSEP ISLAM MODERAT}

Istilah Islam Moderat bukan sengaja dibuat-buat tanpa ada dasarnya sama sekali, melainkan istilah Islam Moderat sudah memiliki konsep dan landasan yang jelas. Bahkan, istilah Islam moderat muncul dengan dasar atau landasan teologis dan ontologis (sesuatu yang bersifat konkret). Istilah Islam moderat ialah bagian dari ajaran Islam yang universal. Istilah Islam moderat memiliki padanan dengan istilah Arab ummatan wasathan atau al-din al-wasath. al ini sebagai mana firman Allah SWT,

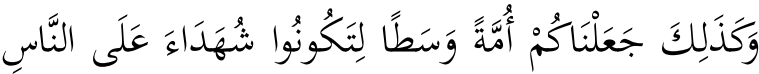

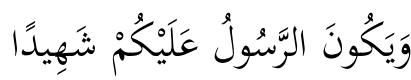

"Dan demikianlah Aku (Tuhan) jadikan kalian umat yang "wasat" (adil, tengah-tengah, terbaik) agar kalian menjadi saksi (syubada') bagi semua manusia, dan agar Rasul (Mubammad SAW) menjadi saksi (syahid) juga atas kalian.” (QS. Al-Baqarah:143).

Istilah Umatan wasathan dalam ayat tersebut berarti "golongan atau agama tengah". Kata "wasat" dalam ayat di atas, jika merujuk kepada tafsir klasik seperti al-Tabari atau alRazi, mempunyai tiga kemungkinan pengertian, yakni: umat yang adil, tengahtengah, atau terbaik. Ketiga pengertian itu, pada dasarnya, saling berkaitan.

18 Davidoff Linda, Psikologi Suatu Pengantar, (Jakarta: Erlanga, 1988), h. 248
Sebagai istilah untuk penggolongan corak pemikiran dan gerakan istilah "Islam moderat" diperlawankan dengan istilah lain, yaitu Islam radikal. Islam moderat, dalam pengertian yang lazim kita kenal sekarang, adalah corak pemahaman Islam yang menolak cara-cara kekerasan yang dilakukan oleh kalangan lain yang menganut model Islam radikal. ${ }^{19}$

Paham Islam moderat memiliki beberapa nilai-nilai luhur yang harus diperhatikan, antara lain : ${ }^{20}$

Tawassuth. Yang dimaksud dengan sikap tawasuth disini adalah sikap tengahtengah, sedang-sedang, tidak ekstrim kiri ataupun ekstrim kanan. Ini disarikan dari firman Allah SWT:

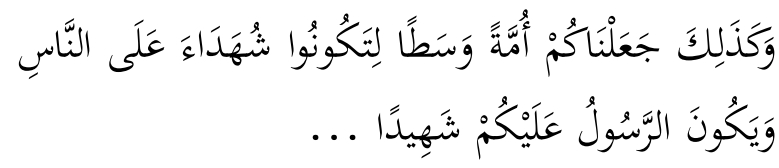

Dan demikianlah kami jadikan kamu sekalian (umat Islam) umat pertengahan (adil dan piliban) agar kamu menjadi saksi (ukuran penilaian) atas (sikap dan perbuatan) manusia umumnya dan supaya Rosulloh menjadi saksi (ukuran penilaian) atas (sikap dan perbuatan) kamu sekalian... (QS alBaqarah: 143). ${ }^{21}$

Tawazun. Yang dimaksud dengan tawazun disini adalah seimbang dalam segala hal, temasuk dalam penggunaan dalil 'aqli (dalil yang bersumber dari akal pikiran rasional) dan dalil naqli (bersumber dari Alquran dan Hadits). Firman Allah SWT:

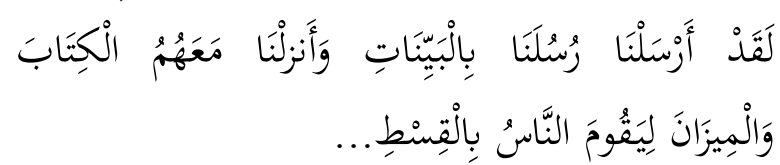

19

Didownloud dari mynewblogaddressislam.blogspot.co.id pada tanggal 28 Juli 2017

20

Didownloud

dari

http://www.nu.or.id/post/read/16551/karakter-

tawassuth-tawazun-i039tidal-dan-tasamuh-dalam-aswaja. Pada tanggal 1 Februari 2017

21 Depag RI, Al-Qur'an dan Terjemahanya, (Bandung: Yayasan Penyelengara Penerjemah Al-Qur'an Depag RI, 2009), h.22 
Sunguh kami telah mengutus rasul-rasul kami dengan membawa bukti kebenaran yang nyata dan telah kami turunkan bersama mereka al-kitab dan neraca (penimbang keadilan) supaya manusia dapat melaksanakan keadilan... (QS al-Hadid: 25) ${ }^{22}$

Ayat di atas menjelaskan kepada kita bahwa selain al-kitab ada lagi al-mizan yang dijadikan pijakan dalam menjalankan keadilan di dunia ini. Para ulama kemudian menafsiri al-Mizan dengan akal pikiran yang sehat. Namun sesuai dengan ayat di atas yang menjadi barometer awal adalah al-kitab baru kemudian al-mizan bukan dibalik al-mizan kemudian al-kitab.

I'tidal. Yang dimaksud dengan i'tidal disini adalah tegak lurus. Konsisten dalam melaksanakan aturan tidak melihat unsur benci atau suka. Firman Allah SWT:

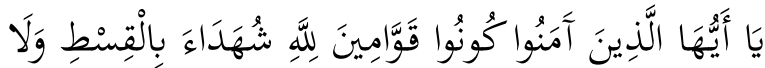

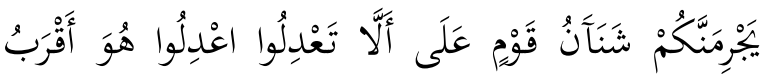

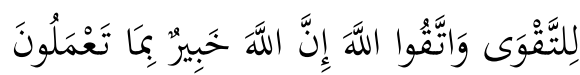

Wahai orang-orang yang beriman hendaklah kamu sekalian menjadi orang-orang yang tegak membela (kebenaran) karena Allah menjadi saksi (pengukur kebenaran) yang adil. Dan janganlah kebencian kamu pada suatu kaum menjadikan kamu berlaku tidak adil. Berbuat adillah Karena keadilan itu lebih mendekatkan pada taqwa. Dan bertaqwalah kepada Allah, karena sesunggubnya Allah Maha Melihat apa yang kamu kerjakan. (QS al-Maidah: 8) ${ }^{23}$

Ayat ini menegaskan bahwa keadilan bisa terwujud jika unsur-unsur kebencian terhadap seseorang atau golongan tertentu dihilangkan. Jika unsur kebencian ini tidak dihilangkan maka hanya akan melahirkan ketidakadilan ditengah tengah masyarakat.

Tasamub. Yang dimaksud dengan sikap tasamuh atau toleransi disini yakni sikap menghargai perbedaan serta menghormati orang yang memiliki prinsip hidup yang tidak sama. Namun bukan berarti mengakui atau membenarkan keyakinan yang berbeda

22 Ibid., h.531

${ }^{23}$ Ibid., h.108 tersebut dalam meneguhkan apa yang diyakini. Firman Allah SWT:

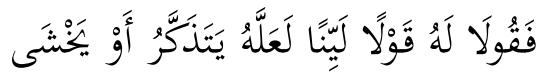

Maka berbicaralah kamu berdua (Nabi Musa AS dan Nabi Harun AS) kepadanya (Fir'aun) dengan kata-kata yang lemah lembut dan mudah-mudahan ia ingat dan takut. (QS. Thaha: 44) ${ }^{24}$

Walaupun Firaun mimiliki keyakinan yang berbeda dengan nabi musa, beliau tetap disuruh berkata lembut dengan fir'an. kelembutan disini merupakan manifestasi dari sikap toleransi namun bukan bermakna membenarkan keyakinannya Fir'aun.

\section{ANALISIS DAN PEMBAHASAN DATA PENELITIAN}

Berikut ini Beberapa persepsi masyarakat Kota Bengkulu terhadap paham Islam Moderat, antara lain:

Paham Islam Moderat adalah ajaran Islam yang bersifat tasamub (toleran), tawazun (berimbang), i'tidal (lurus) dan tawasuth (sedang-sedang)

Sebagian Masyarakat Kota Bengkulu memiliki persepsi tentang paham Islam Moderat sebagai Islam yang toleran terhadap perbedaan perbedaan yang ada ditengahtengah Masyarakat. hal ini seperti data yang telah peneliti dapatkan, antara lain;

"Islam Moderat adalab Islam yang lebih menekankan sisi bumanis dan sisi toleran terhadap sesama muslim dan non muslim. Selain itu Islam Moderat adalab Islam yang lebih menerima perbedaan yang ada tengah-tengah masyarakat. Islam itu agama yang mudab bukan agama yang sulit bukan pula agama yang keras." 25

Selanjutnya, "Sepengetahuan saya Islam Moderat bukan Islam yang membawa ajaran baru. Sisi moderat memang sudah melekat pada agama Islam. Memunculkan istilab Islam Moderat untuk mensyiarkan sisi toleransi dan keramahan agama

\footnotetext{
${ }^{24}$ Ibid., h.314

25 Ustat Busthomi, wawancara pada tanggal 5
} Juni 2017 
Islam bukan berarti membuat agama baru atau sekte baru dalam agama Islam."26

Selanjutnya, "Islam Moderat itu bukan Islam yang memibake aliran tertentu yang ada dalam Islam. semua aliran dalam Islam diterima karena aliran ini lebih menekankan nilai-nilai kebersamaan dan toleransi. jika ada aliran yang berbeda paham ya disilabkan asal tidak mengangu serta menyalabkan aliran lain ${ }^{, 27}$

Selanjutnya, "Paham Islam Moderat adalab ajaran yang mengembangkan nilai-nilai tasamuh, nilai i'tidal, nilai tawazun dan nilai tawasuth. Nilai-nilai ini sudab sejak jaman dabulu dan terus dipelihara binga saat ini. Kalau sekarang man dipopulerkean lagi malah bagus." 28

Selanjutnya, "Islam Moderat adalah Islam yang tengah-tengah. Memahami ajaran Islam selain mengunakan dilil naqli juga mengunakan dalil Aqli. aliran yang dalam bermasyarakat memadukan dua dalil ini menurut saya adalah aliran yang moderat. ${ }^{, 29}$

Dari data-data di atas dapat ditarik kesimpulan wahwa persepsi masyarakat Kota Bengkulu tentang Islam Moderat adalah Islam yang toleran. Mereka melihat sisi toleransi ini muncul ketika ada perbedaan-perbedaan yang terjadi di tengah-tengah masyarakat.

Namun, yang dimaksud dengan sikap tasamuh atau toleransi disini yakni sikap menghargai perbedaan serta menghormati orang yang memiliki prinsip hidup yang tidak sama, bukan berarti mengakui atau membenarkan keyakinan yang berbeda.

Persepsi masyarakat ini sesuai dengan firman Allah SWT:

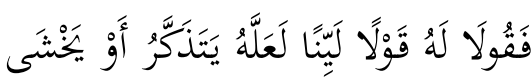

Maka berbicaralah kamu berdua (Nabi Musa AS dan Nabi Harun AS) kepadanya (Fir'aun) dengan

2017

${ }^{26}$ Ahmad Zaid, wawancara pada tanggal 7 Juni

${ }^{27}$ Boby, wawancara pada tanggal 7 Juni 2017 5 Juni 2017

${ }^{28}$ Ustat Ahmad Sahel, wawancara pada tanggal

29 Asmuki, wawancara pada tanggal 14 Juni kata-kata yang lemah lembut dan mudah-mudahan ia ingat dan takut. (QS. Thaha: 44) ${ }^{30}$

Walaupun Firaun mimiliki keyakinan yang berbeda dengan Nabi Musa, beliau tetap disuruh berkata lembut dengan Fir'aun. kelembutan disini merupakan manifestasi dari sikap toleransi namun bukan bermakna membenarkan keyakinannya Fir'aun.

Data di atas juga menunjukan bahwa persepsi masyarak tentang Islam Moderat adalah Islam yang tawazun (berimbang), berimbang disini berarti dalam memahami Islam dilakukan secara proporsional dengan memadukan antara dalil-dalil yang bersifat naqli dengan dalil-dalil yang bersifat aqli. Pemahaman seperti ini diilhami dari Firman Allah SWT Surat Al-Hadid Ayat 25, yang berbunyi

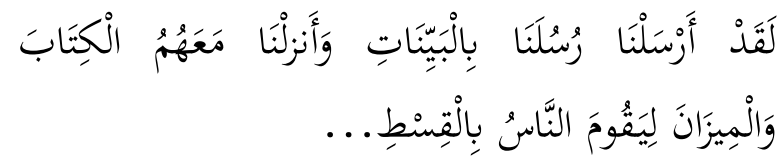

Sunguh kami telab mengutus rasul-rasul kami dengan membawa bukti kebenaran yang nyata dan telah kami turunkan bersama mereka al-kitab dan neraca (penimbang keadilan) supaya manusia dapat melaksanakan keadilan... (QS al-Hadid: 25)

Ayat di atas menjelaskan bahwa selain al-kitab ada lagi al-mizan yang dijadikan pijakan dalam menjalankan keadilan di dunia ini. Para ulama kemudian menafsirkan al-Mizan dengan akal pikiran yang sehat. Namun sesuai dengan ayat di atas yang menjadi barometer awal adalah al-kitab baru kemudian al-mizan bukan dibalik al-mizan kemudian al-kitab.

Data di atas juga menunjukan bahwa persepsi masyarak tentang Islam Moderat adalah Islam i'tidal (lurus). Islam yang dalam melihat fakta sosial dimasyarakat lebih realistis tidak didasarkan atas unsur like atau dislike. Segala sesuatu apabila dilihat dari sisi dislike nya saja maka seberapapun bagusnya akan tetap terlihat jelak demikan juga sebaliknya segala sesuatu jika dilihat dari sisi like-nya maka seberapapun jeleknya akan terlihat 
bagus. Hal ini tentu tidak baik dalam menjaga tatanan bermasyarakat sehinga perlu keberanian untuk berlaku I'tidal dalam bersikap. Pemahaman ini sebenarnya dipahami dari Firman Allah,

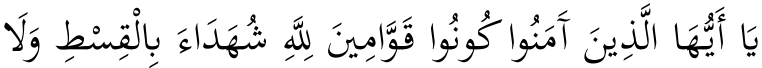

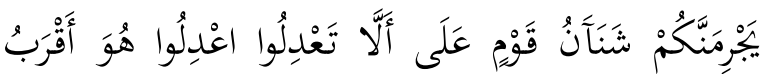

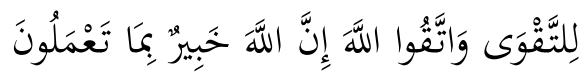

Wahai orang-orang yang beriman hendaklah kamu sekalian menjadi orang-orang yang tegak membela (kebenaran) karena Allah menjadi saksi (pengukur kebenaran) yang adil. Dan janganlab kebencian kamu pada suatu kaum menjadikan kamu berlaku tidak adil. Berbuat adillah karena keadilan itu lebih mendekatkan pada taqwa. Dan bertaqwalah kepada Allah, karena sesunggubnya Allah Maha Melibat apa yang kamu kerjakan. (QS al-Maidah: 8)

Ayat ini menegaskan bahwa keadilan bisa terwujud jika unsur-unsur kebencian terhadap seseorang atau golongan tertentu dihilangkan. Jika unsur kebencian ini tidak dihilangkan maka hanya akan melahirkan ketidakadilan ditengah tengah masyarakat.

Data di atas juga menunjukan bahwa persepsi masyarak tentang Islam Moderat adalah Islam tawasuth (sedanga-sedang), tidak terlalu condong ekstrim maupun tidak liberal. Memahami Islam yang terlalu ekstrim akan melahirkan tindakan anarkis yang membabi buta sedangkan memahami Islam secara liberal akan melahirkan sikap mengampangan syari'at. Kedua sikap ini baik yang bersifat ekstrimis maupun yang liberal sama-sama hanya akan merusak Islam dari dalam. Memahami Islam harus dari sisi wastiyah terkadang Islam mempunyai sisi keras tapi terkadang juga punya sisi lembut. Islam tidak dipahami selalu keras terus atau selalu lembut terus akan tetapi harus dipahami sesuai dengan porsinya masing-masing.

\section{Paham Islam Moderat adalah ajaran Islam yang bersifat Rahmatan Lil Alamin}

Sebagian Masyarakat Kota Bengkulu memiliki persepsi tentang paham Islam Moderat sebagai Islam yang Rahmatan Lil Alamin. Islam yang bisa menjadi rabmat bukan untuk kaum muslim saja melainkan untuk seluruh makhluk hidup yang ada di dunia ini. hal ini seperti data yang telah peneliti dapatkan, antara lain;

"Islam Moderat adalah Islam yang bisa mengimplementasikan spirit rabmatan lil alamin, apa pun nama aliranya kalau rub-nya adalah rabmat (kasib saying) itu bagus. ketika kita melibat pelaku kemaksiatan kita harus menegurnya atas dasar kasib sayang bukan atas dasar binaan. sehinga bisa menjamin keiklasan kita dalam berdakwah',31

Selanjutnya, "Islam Moderat adalam pabam yang yang labir dari semangat hadis nabi ikbtilafi fi ummati rohmatun (perbedaan yang ada pada umatku adalah rahmat). sehinga mereka mengangap hal wajar kalau dalam Islam terdapat banyak perbedaan dalam memahami ajaran Islam." 32

Dari data di atas bisa diketahui bahwa yang dimaksud dengan Islam Moderat adalah Islam yang rabmatan lil alamin (Islam yang menjadi rahmat bagi seluruh alam). Islam yang menjadikan kasih sayang sebagai landasan dalam perjuangan dakwahnya. Jika melihat terdapat dalam suatu daerah ada kemaksiatan yang sedang terjadi maka proses penghentian maksiat tersebut tidak dilakukan dengan caracara yang kasar melainkan dilakukan dengan proses yang santun. Dasar pelarangan terjadinya maksiat adalah kasih sayang bukan karena menghina, mencela atau mengolokolok pelaku maksiat.

Demikian juga bila terjadi perbedaan pendapat dalam memahami sesuatu yang terjadi di masyarakat maka tidak serta merta langsung mengklaim pendapatnya sendiri yang paling benar dan menyalahkan pendapat orang lain, melainkan mengangap perbedaan adalah

31 Ustat Ahmad Arifin, wawancara pada tanggal 19 Juni 2017

32 Niamulloh, wawancara pada tanggal 9 Juni 2017 
suatu yang wajar bahkan dari perbedaan ini bila bisa dimenej dengan baik maka akan menjadi rahmat bersama. Bukan perbedaan sebenarnya yang menjadi masalah tapi ketidak mampuan mengelola perbedaan ini lah yang bisa jadi masalah. Perbedaan merupakan suatu keniscayaan yang pasti ada di masyarakat sehinga tidak mungkin di hilangkan. Oleh karena itu, yang terpenting adalah cara memenajnya hinga menjadi suatu rahmat bagi masyarakat.

\section{Paham Islam Moderat adalah Ajaran Islam yang Bersifat Humanis, Lembut, Santun, Tidak Anarkis dan Cinta Damai}

Sebagian Masyarakat Kota Bengkulu memiliki persepsi tentang paham Islam Moderat sebagai Islam yang humanis, lembut, santun, tidak anarkis dan cinta damai. Hal ini seperti data yang telah peneliti dapatkan, antara lain;

"Islam Moderat adalah Islam yang lebih menekankan sisi bumanis dan sisi toleran terbadap sesama muslim dan non muslim. Selain itu Islam Moderat adalah Islam yang lebih menerima perbedaan yang ada tengah-tengah masyarakat. Islam itu agama yang mudah bukan agama yang sulit bukan pula agama yang keras." 33

Selanjutnya, "Islam Moderat adalah Islam yang tidak anarkis, cinta damai dan toleran. jika Negara damai ekonomi juga bisa berkembang dengan baik. paham moderat harus diajarkan keanak-anak kita sehinga kedepan paham anarkis bisa bilang. bidup tidak nyaman kalau kita dibantui dengan kondisi yang tidak stabil." ${ }^{34}$

Selanjutnya, "Islam Moderat adalah Islam yang tidak memaksakan ajarannya kepada orang lain. bila konteksnya bernegara maka yang digunakan ya aturan bernegara. misalkan muncul masalah atau kejahatan dimasyarakat kan tingal lapor saja kepibak berwajib nanti akan diselesaikan

\footnotetext{
Juni 2017

33 Ustat Busthomi, wawancara pada tanggal 5

${ }^{34}$ Dani, wawancara pada tanggal 22 Juni 2017
}

oleb mereka. tidak perlu lab kita anarkis atan berbuat radikal dengan maen bakim sendiri."

Selanjutnya, "Kalau tidak salah Islam Moderat itu Islam yang mudah diajak diskusi, mudah di ajak berdilog dan mudah menerima kebenaran. Bila anda teriak samapai tengorokan kering "saya Islam Moderat saya Islam Moderat" tapi diri anda susab kalau diajak berdialog maka sebenrnya anda adalab penganut Islam ekstrimis." ${ }^{\text {"36 }}$

Selanjutnya, "Islam Moderat mungkin Islam yang tidak suka berperang dan membunuh manusia yang tidak sepaham dengan aliranya. lawan dari Islam Moderat adalah Islam radikal yang menyukai kekerasan dan tidak segan-segan untuk berperang. paham radikal sangat berbahaya bila dibiarkan tumbuh dinegara kita. Tentu kita tidak ingin Negara yang kita cintai ini seperti Negara di timur tengah yang hancur akibat perang saudara. Negara kita Negara yang damai oleh karena itu harus kita jaga secara bersama-sama kedamainya. kalau ada paham radikal yang mencoba menyusup harus kita lawan secara bersama-sama." ${ }^{37}$

Selanjutnya, "Islam Moderat adalah Islam yang cinta damai dan tidak suka berperang. berbeda dengan Islam radikal yang sukanya mengobarkan perang dimana-mana seperti ISIS." 38

Selanjutnya, "Menurut saya Islam Moderat itu bukan Islam ekstimis. artinya apapun organisasinya kalau mengusung nilai-nilai yang santun, toleran, cinta damai dan menerima perbedaan pendapat dengan lapang dada adalah Islam Moderat. jadi Islam Moderat bisa menjelma menjadi banyak organisasi tidak tertentu pada ormas tertentu saja." 39

Selanjutnya, "Islam Moderat adalab Islam yang anti kekerasan dan anti terorisme. paham ini sangat mengecam para pelaku bom bunub diri. yang betul kalau mau jibad ya kepalestina saja kearena

2017

35 Anto, wawancara pada tanggal 22 Juni 2017

${ }^{36}$ Sairi, wawancara pada tanggal 16 Juni 2017

37 Nasrun, wawancara pada tanggal 22 Juni Juni 2017

38 Agnes Cristina, wawancara pada tanggal 23

39 Sakirman, wawancara pada tanggal 9 Juni 2017
Wahyu Abdul Jafar
Persepsi Masyarakat Kota Bengkulu.... 
memeang di Indonesia tidak perlu perang untuk bisa beribadah." 40

Dari data-data di atas dapat diketahui bahwa persepsi masyarakat Kota Bengkulu mengenai Islam Moderat adalah Islam yang humanis, lembut, santun dan cinta damai. Islam humanis disini maksudnya Islam yang memanusiakan manusia. Manusia adalah makhluk yang memiliki adab dan etika dalam bermasyarakat, sehinga dalam segala aspek kehidupanya apabila ada masalah harus diselesaikan dengan cara yang ber-adab dan ber-etika juga, jangan sampai diselesaikan dengan cara cara yang hewani yakni dengan cara bertarung dan lain sebagainya. Tindakan anarkis serta main hakim senderi merupakan manefestasi dari cara cara hewani ketika menyelesaikan masalah.

Islam adalah agama yang cintai damai dan tidak menyukai terjadinya peperangan. Tindakan teror dan anarkis sangat dilarang dalam Islam bahkan tindakan seperti inilah yang merusak citra Islam. Sering sekali peperangan yang terjadi di Negara-negara timur tengah mengatasnamakan perjuangan agama Islam padahal sebenarnya mereka hanya merebutkan kekuasan dan jabatan semata. Islam tidak pernah menganjurkan perang kecuali dalam kondisi terdesak dimana sudah tidak ditemukan solusi jalan keluar lagi. Perang ini pun harus dilakukan dengan penuh adab dan etika dimana wanita dan anak-anak tidak boleh dibunuh. Hal ini berbeda dengan fakta peperangan yang mengatasnamakan agama Islam saat ini dimana banyak mengorbankan anak anak dan para wanita.

\section{Paham Islam Moderat Adalah Ajaran Islam Yang Membuka Diri Dengan Kemajuan Dan Selaras Dengan Konsep Kenegaraan Indonesia}

40 Ustat Zamroni, wawancara pada tanggal 12 Juni 2017
Sebagian Masyarakat Kota Bengkulu memiliki persepsi tentang paham Islam Moderat sebagai Islam yang membuka diri dengan kemajuan dan selaras dengan konsep kenegaraan Indonesia. hal ini seperti data yang telah peneliti dapatkan, antara lain;

"Islam Moderat itu Islam kekinian bila diibaratkan sebuah tren. Islam yang tidak kolot dan Islam yang bisa membuka diri dengan kemajuan dan kemajemukan masyarakat moderen."^11

Selanjutnya, "Islam Moderat kalau menurut saya Islam yang bisa memadukan konsep keagamaan dengan konsep kenegaraan secara proposional. bila bisa memadukan dengan baik konflik horizontal misi diminimalisir. Negara kita adalah Negara bukum jadi biar bukum yang memutuskan benar atau salahnya perbuatan jangan maen hakim sendiri apalagi sampai melakukan perbuatan anarkis."

Selanjutnya, "Islam Moderat barus memiliki jiwa besar, bila ada orang lain sedang berdakwah yang berbeda aliran jangan maen buburbubarin sembarangan tapi lakukanlah sesuai dengan prosedural, Islam Moderat adalah Islam yang menghargai perbedaan." 43

Selanjutnya, "Islam Moderat itu Islam yang tidak fanatic buta. orang kalau sudah fanatic buta susah benerima kebenaraya. mereka berangapan hanya merekalah yang benar sedangkan yang lain salah semua. dengan adanya sosialisai yang baik kepada masyarakat terkait paham Islam Moderat ini, saya berharap fanatisme yang ada ditengah-tengah masyarakat bisa berkurang." 44

Dari data-data di atas dapat diketahui bahwa persepsi sebagian masyarakat Kota Bengkulu tentang Islam Moderat adalah Islam yang yang membuka diri dengan kemajuan dan selaras dengan konsep kenegaraan Indonesia.

\footnotetext{
2017 2017 42 Andika, wawancara pada tanggal 20 Juni Juni 2017

43 Ustat Efendi, wawancara pada tanggal 16 16 Juni 2017
}

41 Farhan, wawancara pada tanggal 20 Juni 
Islam Moderat adalah Islam yang menyerab hal-hal baru yang bersifat positif sekaligus bisa melakukan filterisasi terhadap hal-hal yang bersifat negatif. Tidak semua hal yang baru itu harus ditolak namun cukup dilakukan filterisasi terhadap hal-hal yang bersifat negatif. Demikan juga dalam konteks kenegaraan, kehadiran agama Islam harus bisa memberikan warna yang sangat signifikan dalam kehidupan bernegara. Undang-undang serta peraturanperaturan yang dibuat oleh Negara harus selaras dengan agama Islam.

\section{Paham Islam Moderat Adalah Ajaran Islam Islam Yang Mengedepankan Nilai Nilai Persatuan Dan Keutuhan Berbangsa Dan Bernegara}

Sebagian Masyarakat Kota Bengkulu memiliki persepsi tentang paham Islam Moderat sebagai Islam yang mengedepankan nilai nilai persatuan dan keutuhan berbangsa dan bernegara. hal ini seperti data yang telah peneliti dapatkan, antara lain;

"Menurut saya, Islam Moderat adalah Islam yang mengedepankan nilai nilai persatuan dan keutuhan berbangsa dan bernegara. Indonesia itu terdiri dari beraneka ragam ras, suku dan agama. jika antar warganya tidak memiliki sikap moderat mau jadi apa bangsa kita. saya sangat mendukung pabam Islam Moderat sekalipun saya tidak beragama Islam demi menjaga keutuhan dan persatuan bangsa Indonesia." 45

Selanjutnya, "Islam Moderat sangat mendukung NKRI. Islam di Indonesia yang tidak mendukung NKRI pasti berbaluan radikal." ${ }^{\text {"46 }}$

Selanjutnya, "Islam Moderat adalah Islam yang mendukung NKRI dengan mempererat rasa persatuan dan kesatuan bangsa."

2017

45 Nasution, wawancara pada tanggal 24 Juni

2017

46 Ardian, wawancara pada tanggal 25 Juni 21 Juni 2017
Dari data di atas dapat diketahui bahwa persepsi masyarakat Kota Bengkulu terhadap Islam Moderat adalah Islam yang mengedepankan nilai nilai persatuan dan keutuhan berbangsa dan bernegara. Konsep ini selaras dengan spirit hadis bubbul wathon minal iman (cinta tanah air adalah sebagian dari iman). Aliran atau ajaran suatu ormas tertentu yang memiliki keinginan untuk merusak persatuan dan kesatuan bangsa Indonesia adalah aliran yang tidak sejalan dengan nilainilai keIslaman karena justru bubbul wathon atau cinta tanah air itu diajarkan dalam Islam.

\section{Paham Islam Moderat Adalah Ajaran Islam Yang Lebih Menekankan Sisi Amar Ma'rufnya Dari Pada Sisi Nahi Mungkarnya}

Sebagian Masyarakat Kota Bengkulu memiliki persepsi tentang paham Islam Moderat sebagai Islam yang lebih menekankan sisi amar ma'rufnya dari pada sisi nahi mungkarnya. hal ini seperti data yang telah peneliti dapatkan, antara lain;

"Islam Moderat adalah Islam yang lebih menonjolkan sisi amar ma'rufnya dan apabila ada kemaksiatan lebih mengedepankan sisi persuasive. konsep ini bagus dikembangkan pada masyarakat yang plural seperti Indonesia. paham ini penting untuk terus disebarluaskan demi menjaga keharmonisan bermasyarakat." 48

Dari data di atas dapat disimpulkan bahwa persepsi sebagian masyarakat Kota Bengkulu tetang Islam Moderat adalah Islam yang lebih menekankan sisi amar ma'rufnya dari pada sisi nahi mungkarnya. Biasanya dalam berdawah materinya berisi tentang Fadhoilul A'mal (keutamaan-keutamaan amal). Dakwah mereka bisanya lebih cepat diterima oleh masyarakat karena sifatnya memberi motivasi bukan menyalahkan atau memvonis haram. 


\section{Paham Islam Moderat Adalah Ajaran Islam Yang Bersifat Tegas Untuk Urusan Akhirat Dan Lentur Untuk Urusan Dunia}

Sebagian Masyarakat Kota Bengkulu memiliki persepsi tentang paham Islam Moderat sebagai Islam yang bersifat tegas untuk urusan akhirat dan lentur untuk urusan dunia. hal ini seperti data yang telah peneliti dapatkan, antara lain;

'Islam Moderat itu Islam yang kalau untuk urusan dunia tidak terlalu mengejar dan lebih toleran sedangkan kalau untuk urusan akbirat maka tidak bisa ditawar-tawar lagi. Contoh kecil, bila adzan di masjid sudah berkomandang maka harus segera ke masjid untuk sholat dan tidak menunda-nunda dengan alasan masih sibuk."49

Selanjutnya, "Islam Moderat adalah Islam yang toleransi dalam konteks bermuamalah. Moderat harus ditempatkan pada porsi yang sebenarnya jangan ditempatkean pada hal-bal yang melampuai batas itu namanya kebablasan atau liberal. Namanya nanti tidak moderat lagi. misalnya jangan tempat moderat pada hal-bal prinsip yang bersifat taubid. Ajaranajaran prinsip dalam agama Islam tidak boleh ditawar tawar lagi. seperti masalah kepemimpinan dalam Islam. ${ }^{, 50}$

Dari data di atas bisa diketahui bahwa sebagian Masyarakat Kota Bengkulu memiliki persepsi tentang paham Islam Moderat adalah sebagai Islam yang bersifat tegas untuk urusan akhirat dan lentur untuk urusan dunia. Akhirat disini bermakna hal-hal yang bersifat ketauhidan seperti sifat-sifat tuhan, tuhan itu esa dan lain sebagainya. Dalam bahasa yang sederhana lagi persoalan akhirat disini bisa juga dimaknai dengan rukun iman dan rukun Islam. Sedangkan urusan dunia adalah urusan kemasyarakatan, seperti urusan jual beli, ketetangaan dan lain sebagainya.

\footnotetext{
${ }^{49}$ Kiki, wawancara pada tanggal 16 Juni 2017

${ }^{50}$ Ustat Wahyudi, wawancara pada tanggal 12 Juni 2017
}

Paham Islam Moderat Adalah Ajaran Islam Yang Bersifat Liberal Dan Sesat

Sebagian Masyarakat Kota Bengkulu memiliki persepsi tentang paham Islam Moderat sebagai Islam yang bersifat liberal dan sesat. hal ini seperti data yang telah peneliti dapatkan, antara lain;

"Islam Moderat saat ini banyak ditungangi oleh aliran liberal dalam Islam. Kalau menurut saya Islam Moderat itu nama lain dari Islam liberal karena memeng sangat mirip pola pikir para penganutnya." 51

Selanjutnya, "Islam Moderat itu sesat, aliran yang mengunakan akal sebagai pedoman adalah aliran sesat dan menyimpang dari yang diajarkan oleb Rosullulob SAW., Islam yang betul adalah LDII dimana Alquran dan hadis dijadikan dasar utam dalam berpijak bukan akal. kalau akal yang dijadikan dasar maka yang muncul adalah akal-akalan". ${ }^{52}$

Selanjutnya, "Yang saya pahami Islam Moderat itu Islam yang ngawur, meraka asal-asalan dalam beribadah dan semaunya sendiri dalam membuat bukum. aliran ini sengaja dilabirkan oleb orang-orang liberal yang mendewa-dewakan kebebasan tak terbatas." 53

Dari data-data di atas dapat diketahui bahwa sebagian Masyarakat Kota Bengkulu memiliki persepsi tentang paham Islam Moderat adalah sebagai Islam yang bersifat liberal dan sesat. Liberal pada Islam Moderat terjadi karena tidak ada lagi batasan batasan kebebasan yang digaung-gaunkan oleh kelompok mereka. Hal ini terjadi karena mereka menjadikan akal sebagai barometer utama dalam berdalil, yang akan melahirkan akal-akalan dalam berdalil. Kesesatan yang ada pada Islam Moderat juga karena mereka asalasalan dalam beribadah. Ibadah tidak

${ }^{51}$ Ustat Usman, wawancara pada tanggal 9 Juni

52 Ustat Imam Purwoko, wawancara pada tanggal 15 Juni 2017

${ }^{53}$ Ustat Salim, wawancara pada tanggal 15 Juni 2017 
dilakukan dengan sunguh-sunguh cukup dilakukan dengan sedang sedang saja. Padahal yang bersunguh-sunguh dalam beribadah saja belum tentu diterima ibadahnya apalagi yang sedang-sedang saja kesunguhan dalam beribadahnya.

\section{Paham Islam Moderat Adalah Ajaran Islam Yang Bersifat Bid'ah Dan Melemahkan Umat Islam}

Sebagian Masyarakat Kota Bengkulu memiliki persepsi tentang paham Islam Moderat sebagai Islam yang bersifat bid'ah dan memecah belah umat. hal ini seperti data yang telah peneliti dapatkan, antara lain;

"Islam Moderat itu istilah yang tidak ada dalam ajaran Islam. ini istilah baru dan bid'ah yang dimunculkan untuk memperlemah agama Islam. saya tidak suka kalau Islam itu dipecah belah seolah Islam satu dengan yang lainya berbeda. Ada Islam nusantara ada Islam Moderat ada Islam ekstrimis ada Islam konvensional dan lain sebagainya. Islam itu satu sehinga kalau ingin mengetahui Islam yang sejati ya dilibat dari selurub ajaranya jangan hanya dilibat satu sisi saja." ${ }^{, 4}$

Selanjutnya, "Islam Moderat merupakan bentuk pelemahan terhadap ajaran Islam. umat Islam digiring supaya meningalkan ajaranya secara perlahan-lahan dengan doktrin mengamalkan ajaran Islam cukup sedang sedang saja. umat muslim seharusnya berpegang teguh kepada ajaranya tanpa perlu menawar-nawar lagi. apapun yang diperintabkean dalam syariat Islam harus dipraktekan." 55

Dari data-data di atas diketahui bahwa sebagian Masyarakat Kota Bengkulu memiliki persepsi tentang Islam Moderat sebagai Islam yang bersifat bid'ah dan melemahkan umat Islam. Bid'ah merupakan ajaran yang tidak ada tapi sengaja di ada adakan. Melihat Islam tidak bisa hanya dari satu sisi saja. Islam harus dilihat secara komprehensip baik dari sisi

\footnotetext{
54 Zaini, wawancara pada tanggal 20 Juni 2017

55 Yusuf Romadhoni, wawancara pada tanggal
} 15 Juni 2017 lembutnya ataupun dari sisi kerasnya. Upaya melihat Islam hanya dari sebagian sisinya saja merupakan upaya untuk melemahkan umat Islam karena umat Islam sengaja digiring agar mengamalkan Islam tidak secara komprehensip melainkan cukup mengamalkan sebagian ajarannya saja.

\section{Paham Islam Moderat Adalah Ajaran Islam Yang Bersifat Fatamorgana Dan Memecah Belah Umat Islam}

Sebagian Masyarakat Kota Bengkulu memiliki persepsi tentang paham Islam Moderat sebagai ajaran Islam yang bersifat fatamorgana dan memecah belah umat Islam. hal ini seperti data yang telah peneliti dapatkan, antara lain;

"Paham Islam Moderat sekarang ini masih fatamorgana semata. Saya bingung melihat orang yang selalu mendengung-dengungkna Islam Moderat ternyata tidak moderat juga dalam menerima perbedaan paham yang ada dalam Islam. Mereka toleransi untuk orang-orang yang non muslim tapi tidak toleransi sesama muslim sendiri. contoh ketika melibat orang berjengot mereka benci apabila melibat orang isbal mereka tidak suka. Seharusnya tidak seperti itu, kalau mau moderat ya untuk semua aliran yang ada dalam Islam bukan hanya moderat untuk non Islam." $" 56$

Selanjutnya, "Istilah moderat itu lebel yang sengaja diciptakan oleh pibak asing bagi ormas Islam yang ada di indonesia. Ormas yang kritis dan menentang keras sitem ekonomi kapitalis yang mengancam hegemoni investasi mereka di Indonesia, mereka beri lebel dengan radikal sedangkan ormas yang masib bisa diajak kerja sama dan lebib soft terhadap mereka dilabeli dengan Islam Moderat Islam yang toleran." 57

Dari data-data di atas diketahui bahwa sebagian Masyarakat Kota Bengkulu memiliki persepsi tentang Islam Moderat sebagai ajaran Juni 2017

56 Ahmad Wahid, wawancara pada tanggal 12 ${ }^{57}$ Ustat Zakaria, wawancara pada tanggal 14 Juni 2017 
Islam yang bersifat fatamorgana dan memecah belah umat Islam. Fatamorgana disini muncul karena selama ini mereka memberikan lebel toleran untuk ajaran Islam Moderat mereka sendiri tapi di satu sisi mereka ingin menghancurkan paham dan ajaran yang tidak sejalan dengan mereka. Hal ini seperti pedang yang tajam keluar tapi tumpul kedalam. Ajaran lain harus toleran terhadap Islam Moderat tapi Islam Moderat tidak mau toleran dengan ajaran lain yang tidak sejalan. Pemberian lebel moderat dan tidak moderat juga ternyata didasarkan pada apakah aliran mereka mengancam hegomoni investasi asing di Indonesia. Ormas yang kritis dan menentang keras sitem ekonomi kapitalis yang mengancam hegemoni investasi mereka di Indonesia, mereka beri lebel dengan radikal sedangkan ormas yang masih bisa diajak kerja sama dan lebih soft terhadap mereka dilabeli dengan Islam Moderat Islam yang toleran. Tujuan akhir dari pelebelan ini adalah untuk memecah belah umat Islam sehinga tidak memiliki kekuatan untuk menghancurkan hegomoni investasi asing di Negara Indonesia.

Secara garis besar, persepsi masyarakat Kota Bengkulu terhadap Islam Moderat terbagi menjadi dua kategori, yakni persepsi yang baik dan persepsi yang tidak baik. Untuk lebih jelasnya bisa dilihat pada tabel dibawah ini,

\begin{tabular}{|c|c|c|}
\hline \multirow[t]{2}{*}{ No } & \multicolumn{2}{|c|}{$\begin{array}{c}\text { Persepsi Masyarakat Kota Bengkulu Terhadap } \\
\text { Islam Moderat }\end{array}$} \\
\hline & Persepsi Baik & Persepsi Tidak Baik \\
\hline 1 & $\begin{array}{l}\text { Paham Islam Moderat } \\
\text { adalah ajaran Islam } \\
\text { yang bersifat tasamuh } \\
\text { (toleran), tawazun } \\
\text { (berimbang), i'tidal } \\
\text { (lurus) dan tawasuth } \\
\text { (sedang-sedang) }\end{array}$ & $\begin{array}{lr}\text { Paham } & \text { Islam } \\
\text { Moderat adalah } \\
\text { ajaran Islam yang } \\
\text { bersifat liberal dan } \\
\text { sesat }\end{array}$ \\
\hline 2 & $\begin{array}{l}\text { Paham Islam Moderat } \\
\text { adalah ajaran Islam } \\
\text { yang bersifat Rabmatan } \\
\text { Lil Alamin }\end{array}$ & $\begin{array}{l}\text { Paham } \\
\text { Moderat adalah } \\
\text { ajaran Islam yang } \\
\text { bersifat bid'ah dan } \\
\text { melemahkan umat } \\
\text { Islam }\end{array}$ \\
\hline 3 & Paham Islam Moderat & Paham \\
\hline
\end{tabular}

\begin{tabular}{|l|l|l|}
\hline & $\begin{array}{l}\text { adalah ajaran Islam } \\
\text { yang bersifat humanis, } \\
\text { lembut, santun, tidak } \\
\text { anarkis dan cinta damai }\end{array}$ & $\begin{array}{l}\text { Moderet adalah } \\
\text { Ajaran Islam yang } \\
\text { bersifat fatamorgana } \\
\text { dan memecah belah } \\
\text { umat Islam }\end{array}$ \\
\hline 4 & $\begin{array}{l}\text { Paham Islam Moderat } \\
\text { adalah ajaran Islam } \\
\text { yang membuka diri } \\
\text { dengan kemajuan dan } \\
\text { selaras dengan konsep } \\
\text { kenegaraan Indonesia }\end{array}$ & \\
\hline 5 & $\begin{array}{l}\text { Paham Islam Moderat } \\
\text { adalah ajaran Islam } \\
\text { Islam yang } \\
\text { mengedepankan nilai } \\
\text { nilai persatuan dan } \\
\text { keutuhan berbangsa } \\
\text { dan bernegara }\end{array}$ \\
\hline 6 & $\begin{array}{l}\text { Paham Islam Moderat } \\
\text { adalah ajaran Islam } \\
\text { yang lebih menekankan } \\
\text { sisi amar ma'rufnya dari } \\
\text { pada sisi nahi } \\
\text { mungkarnya }\end{array}$ \\
\hline 7 & $\begin{array}{l}\text { Paham Islam Moderat } \\
\text { adalah ajaran Islam } \\
\text { yang bersifat tegas } \\
\text { untuk urusan akhirat } \\
\text { dan lentur untuk urusan } \\
\text { dunia }\end{array}$ \\
\hline
\end{tabular}

Dari data di atas dapat diketahui bahwa sebagian besar masyarakat kota Bengkulu memiliki persepsi yang baik tentang paham Islam moderat, hal ini dapat dilihat pada table dibawah ini,

\begin{tabular}{|c|l|l|c|}
\hline No & \multicolumn{2}{|c|}{$\begin{array}{c}\text { Persepsi Masyarakat Kota } \\
\text { Bengkulu Terhadap Urgensi } \\
\text { Penyebaran Paham Islam } \\
\text { Moderat }\end{array}$} & $\begin{array}{c}\text { Persentase } \\
\%\end{array}$ \\
\hline $\mathbf{1}$ & $\begin{array}{l}\text { Persepsi } \\
\text { Baik }\end{array}$ & $\begin{array}{l}\text { Ada } \\
\text { persepsi } \\
\text { yang baik }\end{array}$ & $70 \%$ \\
\hline $\mathbf{2}$ & $\begin{array}{l}\text { Persepsi } \\
\text { Tidak Baik }\end{array}$ & $\begin{array}{l}\text { Ada } \\
\text { persepsi } \\
\text { yang tidak } \\
\text { baik }\end{array}$ & $30 \%$ \\
\hline
\end{tabular}

\section{PENUTUP}

Dari pemaparan dan pembahasan data di atas dapat ditarik kesimpulan bahwa Masyarakat Kota Bengkulu memiliki beberapa persepsi tentang paham Islam moderat, antara lain: pertama, Paham Islam Moderat adalah 
ajaran Islam yang bersifat tasamub (toleran), tawazun (berimbang), i'tidal (lurus) dan tawasuth (sedang-sedang). Kedua, Paham Islam Moderat adalah ajaran Islam yang bersifat Rabmatan Lil Alamin. Ketiga, Paham Islam Moderat adalah ajaran Islam yang bersifat humanis, lembut, santun, tidak anarkis dan cinta damai. Keempat, Paham Islam Moderat adalah ajaran Islam yang membuka diri dengan kemajuan dan selaras dengan konsep kenegaraan Indonesia. Kelima, Paham Islam Moderat adalah ajaran Islam yang mengedepankan nilai nilai persatuan dan keutuhan berbangsa dan bernegara. Keenam, Paham Islam Moderat adalah ajaran Islam yang lebih menekankan sisi amar ma'rufnya dari pada sisi nahi mungkarnya. Ketujuh, Paham Islam Moderat adalah ajaran Islam yang bersifat tegas untuk urusan akhirat dan lentur untuk urusan dunia. Kedelapan, Paham Islam Moderat adalah ajaran Islam yang bersifat liberal dan sesat. Kesembilan, Paham Islam Moderat adalah ajaran Islam yang bersifat bid'ah dan melemahkan umat Islam. Kesepuluh, Paham Islam Moderet adalah Ajaran Islam yang bersifat fatamorgana dan memecah belah umat Islam. 


\section{DAFTAR KEPUSTAKAAN}

Abdul Kadir Muahammad, Hukum dan Penelitian Hukum, (PT. Citra Aditya Bhakti, Jakarta, 2004).

Abdul Rahman Shaleh, Muhbib Abdul Wahab, Psikologi Suatu Pengantar Dalam Perspektif Islam, (Jakarta: Kencana, 2004)

Abu Syamsi, wawancara pada tanggal 6 Juni 2017

Agnes Cristina, wawancara pada tanggal 23 Juni 2017

Ahmad Dahlan, wawancara pada tanggal 6 Juni 2017

Ahmad Fasikhudin, Islam Moderat, (Bandung: Insan Kamil, 2010)

Ahmad Wahid, wawancara pada tanggal 12 Juni 2017

Ahmad Zaid, wawancara pada tanggal 7 Juni 2017

Ahmad, wawancara pada tanggal 29 Maret 2017.

Airen Celinesia, wawancara pada tanggal 21 Juni 2017

Ali Zainal, wawancara pada tanggal 14 Juni 2017

Andi, wawancara pada tanggal 22 Juni 2017

Andika, wawancara pada tanggal 20 Juni 2017

Anita, wawancara pada tanggal 23 Juni 2017

Anto, wawancara pada tanggal 22 Juni 2017

Ardian, wawancara pada tanggal 25 Juni 2017

Asmuki, wawancara pada tanggal 14 Juni 2017

Atkinson dkk, Pengantar Psikologi Jilid II, (Batam: Intereksa, 1987)

Badri Yatim, Sejarah Peradaban Islam, (Jakarta : Rajawali Pers, 2010)

Bimo Walgito, Pengantar Psikologi Umum, (Yogyagkarta: Andi Offsed, 1994)

Boby, wawancara pada tanggal 7 Juni 2017

BPS Provinsi Bengkulu, Provinsi Bengkulu Dalam Angka 2016, (Bengkulu : Perum Percetakan

Negara RI Cabang Bengkulu, 2016)

Dani, wawancara pada tanggal 22 Juni 2017

Darto, wawancara pada tangal 24 Maret 2017.

Davidoff Linda, Psikologi Suatu Pengantar, (Jakarta: Erlanga, 1988)

Depag RI, Alquran dan Terjemahanya, (Bandung: Yayasan Penyelengara Penerjemah Alquran

Depag RI, 2009)

Dimyati Mahmud, Psikologi Suatu Pengantar, (Jakarta: BPFE, 1990)

Emanuel, wawancara pada tanggal 23 Juni 2017

Faiz Saputra, wawancara pada tanggal 7 Juni 2017

Farhan, wawancara pada tanggal 20 Juni 2017

Fazlur Rahman, Islam, (Bandung : Pustaka, 1997)

Gracia Stefani, wawancara pada tanggal 23 Juni 2017

Husaini Usman dan Purnomo Setiady Akbar, Metodologi Penelitian Sosial, Jakarta: PT Bumi Aksara, 2003)

Husein Umar, Metode Penelitian Untuk Skripsi dan Tesis Bisnis, (Jakarta, PT Raja Grafindo Persada, 2009)

Ibnu Aqil, wawancara pada tanggal 19 Juni 2017

Igusti Ananta, wawancara pada tanggal 26 Juni 2017

Imade Jaya, wawancara pada tanggal 25 Juni 2017

Irsad Hakim, wawancara pada tanggal 13 Juni 2017 
Jalaluddin Rahmat, Psikologi Umum, (Bandung: Insan kamil, 1984)

Kartini Kartono, Psikologi Umum, (Bandung: Insan Kamil, 1984)

Kiki, wawancara pada tanggal 16 Juni 2017

Kundarto Sahid, wawancara pada tanggal 20 Juni 2016

Lexy J. Moleong, Metodologi Penelitian Kualitatif, (Bandung: PT Remaja Rosdakarya, 2012)

M. Sholikhin, Sejarah Peradaban Islam, (Semarang : Rasail, 2005.)

Mada Kusuma, wawancara pada tanggal 241Juni 2017

Maichel, wawancara pada tanggal 24 Juni 2017

Manshur, wawancara pada tanggal 19 Juni 2017

Mar'at, Sikap Manusia, Perubahan, dan Pengukurannya, (Jakarta: Ghalia Indonesia, 1981)

Maryam, wawancara pada tanggal 19 Juni 2017

Miftahuddin, Dosen Prodi Ilmu Sejarah, Jurusan Pendidikan Sejarah, FISE UNY, "Islam Moderat Konteks Indonesia Dalam Perspektif Historis".

Muhammad Basrowi dan Soeyono, Teori Sosiologi dalam Tiga paradigma (Surabaya: Yayasan Kampusina, 2004)

Muhammad Tholhah Hasan, Ablussunah Wal Jamaah, (Jakarta : Lantabora Press, 2005)

muhshodiq.wordpress.com

mukhsinjamil.blog.walisongo.ac.id

Muzakki, wawancara pada tangal 24 Maret 2017

mynewblogaddressIslam.blogspot.co.id

Nasrun, wawancara pada tanggal 22 Juni 2017

Nasution, wawancara pada tanggal 24 Juni 2017

Niamulloh, wawancara pada tanggal 9 Juni 2017

Nurcholish Madjid, Islam Kemoderenan dan Keindonesiaan, (Bandung : Mizan, 1998.)

Nurul zuriah, Metodologi Penelitian Sosial dan Pendidikan, (Jakarta : PT Bumi Aksara, 2009)

Putu Kusuma, wawancara pada tanggal 26 Juni 2017

Rijal, wawancara pada tangal 27 Maret 2017

Rudi, wawancara pada tanggal 20 Juni 2017

Sairi, wawancara pada tanggal 16 Juni 2017

Sakirman, wawancara pada tanggal 9 Juni 2017

Salman, wawancara pada tanggal 9 Juni 2017

Sarlito Wirawan Sarwono, Pengantar Psikologi, (Jakarta: Bulan Bintang, 1976)

Sherly Kurniawan, wawancara pada tanggal 21 Juni 2017

Sholihan, Modernitas Postmodernitas Agama, (Semarang : Walisongo Press, 2008)

Sri Utami Sa'diyah, Persepsi Siswa Terhadap Guru Pendidikan Agama Islam Yang Ideal, (Situbondo: Ibrahimy Press, 2009)

Su'adah, Fauzik Lendriyono, Pengantar Psikologi, (Bayumedia Publishing,: Malang, 2003)

Sugiyono, Model Penelitian kuantitatif kualitatif, (bandung: Alfabeta, 2010)

Suhidi, wawancara pada tanggal 13 Juni 2017

Sumarna, wawancara pada tanggal 11 Juni 2017

Susanti, wawancara pada tanggal 24 Juni 2017

Syamsul Bakri, "Islam dan Wacana Radikalisme Kontemporer". DINIKA. Vol. 3 No. 1, Januari 2004

Theodore M. Newcomb dkk, Psikologi Sosial, (Bandung: Dipenogoro, 1981)

Ustat Ahmad Arifin, wawancara pada tanggal 19 Juni 2017 
Ustat Ahmad Sahel, wawancara pada tanggal 5 Juni 2017

Ustat Arif Rahman, wawancara pada tanggal 16 Juni 2017

Ustat badrud, wawancara pada tanggal 5 Juni 2017

Ustat Busthomi, wawancara pada tanggal 5 Juni 2017

Ustat Dadang, wawancara pada tanggal 15 juni 2017

Ustat Efendi, wawancara pada tanggal 16 Juni 2017

Ustat Imam Purwoko, wawancara pada tanggal 15 Juni 2017

Ustat Iskandar, wawancara pada tanggal 5 Juni 2017

Ustat Muttaqin, wawancara pada tanggal 19 Juni 2017

Ustat Pendi, wawancara pada tanggal 17 Juni 2016

Ustat Salim, wawancara pada tanggal 15 Juni 2017

Ustat Suyuti, wawancara pada tanggal 14 Juni 2017

Ustat Usman, wawancara pada tanggal 9 Juni 2017

Ustat Wahyudi, wawancara pada tanggal 12 Juni 2017

Ustat Zaini Makmun, wawancara pada tanggal 6 Juni 2017

Ustat Zakaria, wawancara pada tanggal 14 Juni 2017

Ustat Zamroni, wawancara pada tanggal 12 Juni 2017

W. Michel dan N.H. Michel, Essentials of Psychology, (New York: Rndom House Inc., 1980)

Wawan, wawancara pada tanggal 16 Juni 2017

Wayan Saputra, wawancara pada tanggal 25 Juni 2017

Wrightsman, "Social Psychology Indonesia the 80's", sebagaimana dikutip Subyakto, Psikologi

Sosial, (Jakarta: Haruhita, 1988)

Wulan, wawancara pada tanggal 23 Juni 2017

www.m.tribunews.com

www.nu.or.id

www.tempo.co

Yanto, wawancara pada tangal 29 Maret 2017

Yunus, wawancara pada tanggal 16 Juni 2017

Yusuf Romadhoni, wawancara pada tanggal 15 Juni 2017

Zaini, wawancara pada tanggal 20 Juni 2017

Zainudil Al-Afgani, wawancara pada tanggal 6 Juni 2017

Zakiya Yusuf, wawancara pada tanggal 12 Juni 2017 